\title{
Integration of Deep Biosphere Research into the International Continental Scientific Drilling Program
}

by Kai Mangelsdorf and Jens Kallmeyer

doi: 10.2204/iodp.sd.10.0.2010

\section{Introduction and Workshop Goals}

An international workshop on the Integration of Deep Biosphere Research into the International Continental Scientific Drilling Program (ICDP) was held on 27-29 September 2009 in Potsdam. It was organized by the Helmholtz Centre Potsdam GFZ German Research Centre for Geosciences and the University of Potsdam (Germany). Financial support was provided by ICDP. This workshop brought together the expertise of thirty-three microbiologists, biogeochemists, and geologists from seven countries (Finland, Germany, Japan, New Zealand, Sweden, U.K., U.S.A.).

Over the last two decades, microbiological and biogeochemical investigations have demonstrated the occurrence of microbial life widely disseminated within the deep subsurface of the Earth (Fredrickson and Onstott, 1996; Parkes et al., 2000; Pedersen, 2000; Sherwood Lollar et al., 2006).

Considering the large subsurface pore space available as a life habitat, it has been estimated that the biomass of the so-called deep biosphere might be equal to or even larger than that of the surface biosphere (Whitman et al., 1998).

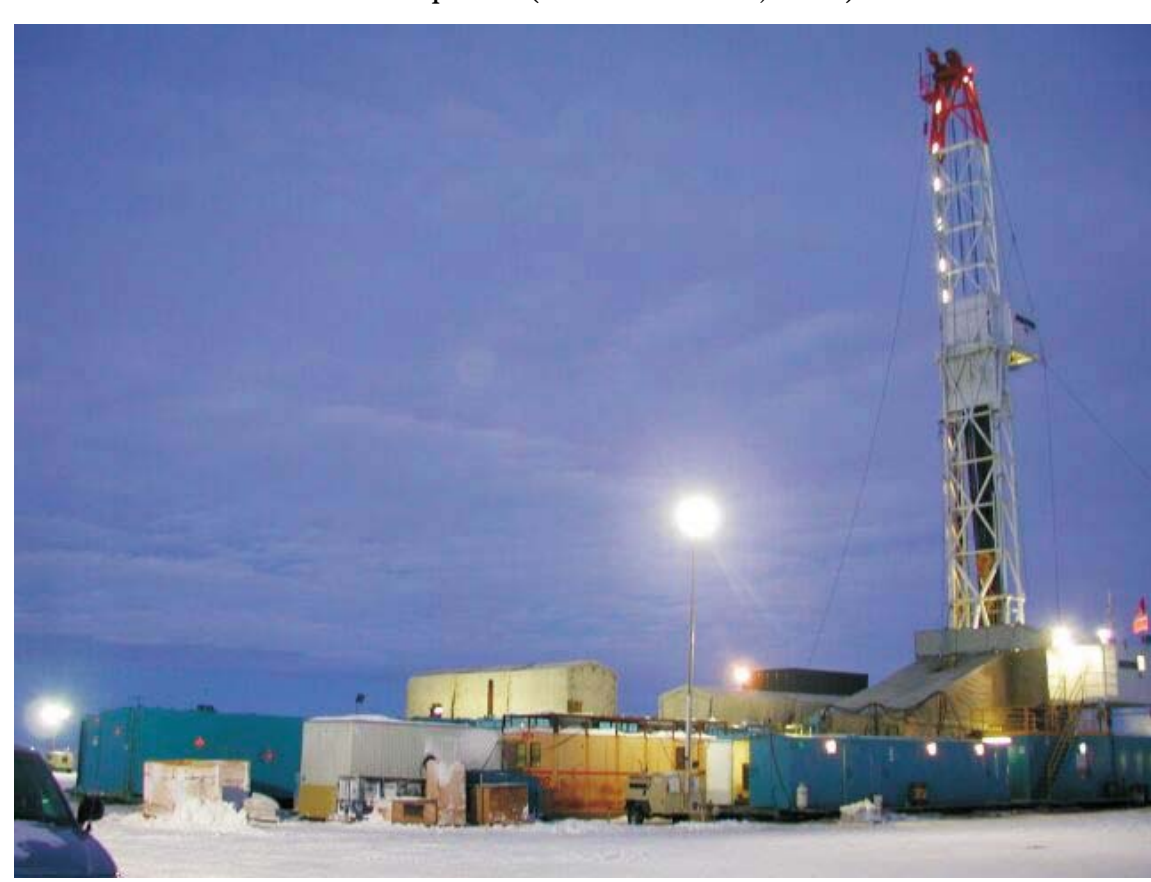

Figure 1. The Mallik Gas Hydrate Research project drill site at the northern edge of the Mackenzie River Delta, Northern Territories Canada. The Mallik project was one of the first ICDP projects containing a deep biosphere component.
Thus, the deep biosphere must play a fundamental role in global biogeochemical cycles over short and long time scales. Its huge size, as well as the largely unexplored biogeochemical processes driving the deep biosphere, makes the investigation of the extent and dynamics of subsurface microbial ecosystems an intriguing and relatively new topic in today's geoscience research. Our knowledge of the deep biosphere is still fragmentary especially in terrestrial environments. While geobiological research is already an integral part in many Integrated Ocean Drilling Program (IODP) sampling missions (Lipp et al., 2008; Roussel et al., 2008; Zink et al., 2003), only a few recent projects within the ICDP have had a geobiological component (Colwell et al., 2005; Gohn et al., 2008; Mangelsdorf et al., 2005). In the recently published book Continental Scientific Drilling - A Decade of Progress and Challenges for the Future, Horsfield et al. (2007) argued that exploration of the "GeoBiosphere" should be an integrated component of the activities of ICDP to correct this imbalance.

Thus, the aim of the workshop was to integrate deep biosphere research into ICDP by 1) defining scientific questions and targets for future drilling projects in terrestrial environments and 2) addressing the technical, administrative and logistical prerequisites for these investigations. According to these goals the workshop was segmented into two parts.

\section{Key Scientific Questions and Identification of New Targets}

Topics for deep biosphere research in terrestrial systems. With the discovery of deep microbial ecosystems in sedimentary basins-as well as microbial life in granites, deep gold mines, and oil reservoirs-the view of the scientific community was opened to a hidden and largely unexplored inhabited realm on our planet (Fredrickson and Onstott, 1996; Parkes et al., 2000; Pedersen, 2000; Sherwood Lollar et al., 2006). From a surface point of view the deep subsurface is an extreme environment. With increasing burial depth, microbial communities have to cope with increasing temperature and pressure, nutrient limitation, limited porosity and permeabil- 
ity as well as a decrease in the available carbon and energy sources, essentially affecting the composition, extent, life habitats, and the living conditions (Horsfield et al., 2007). The rates of microbial cellular activity in the deep biosphere are estimated to be orders of magnitude lower than those in surface environments. Contrary to surface microbes, which generally have doubling times of minutes to months, the average frequency of cell division of deep subsurface microorganisms is within the range of a century (Fredrickson and Onstott, 1996) and defies our current understanding of the limits of life.

In marine and terrestrial sedimentary basins, buried organic matter is the obvious carbon and energy source for deep microbial life. In the upper part of the sediment column it is thought that intense degradation of organic matter initially increases the recalcitrant proportion of the organic material. However, in deeper successions the bioavailability of organic matter might increase again due to the rising temperature with increasing burial depth, affecting the bond stability of potential substrates in the organic matrix (Parkes et al., 2007; Wellsbury et al., 1997; Glombitza et al., 2009). The organic matter in these ecosystems was initially produced by photosynthesis. Therefore, despite the long delay between production and consumption, these systems are ultimately depending on surface processes.

In environments with little buried organic matter-for instance, in igneous rocks-lithoautotrophic microbial communities are able to synthesize small organic compounds from inorganic sources like hydrogen gas and carbon dioxide, and these simple organic compounds can then be utilized by other heterotrophic microorganisms. Such microbial communities, also called Subsurface Lithoautotrophic Microbial Ecosystems (SLiMEs), form entire ecosystems in the deep subsurface, which are completely independent from photosynthetically produced substrates (Fredrickson and Onstott, 1996; Lin et al., 2005; Lin et al., 2006; Sherwood Lollar et al., 2006; Stevens and McKinley, 1995).

The widely disseminated deep biosphere poses fundamental questions such as the following. What kind of microorganisms populate the deep subsurface? What is their extension and where are their limits? How is their life habitat shaped? What metabolic processes do they perform? What carbon and energy sources do they use? What survival strategies do these microorganisms apply? Does microbial life in the subsurface represent early life on Earth? What is their impact on the global carbon cycle and linked to that on the global climate?

Deep microbes not only create (biogenic gas) but also have the potential to destroy fossil energy resources (biodegradation of oils). Also, research on potential life in the subsurface of other planets (e.g., Mars), studies about the safety of deep nuclear waste disposal sites, bioremediation of polluted sites, deep aquifer exploration, and the search for new biomedicals are drivers of deep biosphere research (Rothschild and Mancinelli, 2001).

Thus, the workshop participants defined general key topics for terrestrial deep biosphere drilling.

- Extent and diversity of deep microbial life and the limits of life

- Subsurface activity and metabolism as well as carbon and energy sources for deep microbial life

- Evolution, survival, and adaptation of deep microbial life

- Resources and applications: natural resources provided or degraded by deep microbial communities and the implication on biotechnology applications

- Interaction of the deep biosphere with the geosphere and implication of deep microbial activity on Earth's climate

- Deep biosphere as a model for early life on Earth and life on other planets

The workshop also addressed more specific topics including a potential target for already scheduled ICDP drilling campaigns of forming a base for a future dedicated ICDP deep biosphere project, and sampling and curation standards to support interoperability between different drilling operations.

Diversity and extent of the deep subsurface biosphere. One exciting question is whether deep terrestrial and lacustrine subsurface communities differ from the subseafloor biosphere (and if yes, how)? There are many structural corresponding subterrestrial and subseafloor environments (e.g., subsurface ecosystems in pressure enhanced hyperthermophilic systems and subseafloor hydrothermal vent systems) that allow a comparison of the indigenous subsurface and subseafloor microbial communities.

In addition to the spatial distribution and diversity of deep microbial life, the question on the temporal diversity in a given subsurface location due to changes in the environmental conditions was addressed. To monitor such changes, the installation of monitoring devices (e.g., osmo samplers), measuring the chemistry and flow rates of fluids, and the use of cartridges with different substrate media were suggested as part of the formation of a natural laboratory under in situ conditions.

While investigating the deep biosphere, participants focused on microbial communities. Other components such as phages were mainly overlooked. In the last few years the investigation of phages has become a new topic in deep biosphere research (Engelen et al., 2009). Viral infection of deep microbial communities was discussed as a controlling factor for the deep biosphere through exchange of DNA, killing microorganisms, and also providing essential substrates for non-infected microorganisms due to the viral-induced 
release of cell components from infected cells (the so-called viral shunt). Thus, this intriguing new scientific field should also form an integrated part of future deep biosphere research in terrestrial systems.

Limits of subsurface life. What determines the biogeography of microorganisms in the deep subsurface? Conceivable factors are the grain size, pore space, and permeability of the sediments and rocks. Furthermore, the content, distribution, and kind of organic matter-and, therefore, the availability of carbon and energy sources-as well as deep fluids and ambient temperature play a significant role with all having strong impact on the habitability in the deep realm. Knowing these factors, can we predict the distribution, extent, and composition of the deep microbial communities? Are deep biosphere communities exploiting all low temperature $\left(<150^{\circ} \mathrm{C}\right)$ parts of the rock cycle, and how do the physical and geochemical characteristics of the habitat determine the abundance and distribution of the microbial communities?

In this context it is of interest whether paleopasteurization (Wilhelms et al., 2001) exists in, for instance, organicrich sediments initially subsided to greater depth with corresponding high ambient temperatures and subsequent uplift into temperature regimes that are usually compatible with deep microbial life. Another aspect is how the biogeography of microbial communities of isolated (closed) terrestrial systems (e.g., no contact to meteoric fluid flows) differs from open systems in time and space, especially with respect to speciation and survival strategies (adaptation/repair mechanisms) in the deep biosphere. Are there ecological niches, and is there competition between the deep microorganisms affecting the community structure and evolutionary processes?

Processes and interactions. In sediments the deposited and subsided organic matter forms the carbon and energy sources for the indigenous microbial life. Initially, the recalcitrant proportion of the organic matter increases with ongoing subsidence and maturation. On the other hand, early geothermally driven degradation processes already start at comparable low temperatures $\left(>50^{\circ} \mathrm{C}\right)$ gradually providing again potential substrates for the deep biosphere (Horsfield et al., 2006). Is there an overlap between biogenic and thermogenic processes being a feedstock for deep terrestrial microbial ecosystems, and what is the role and importance of geological processes to sustain biological systems in the deep biosphere?

As we examine the potential feedstock sources for deep microbial life, it is also of interest to investigate the impact of $\mathrm{CO}_{2}, \mathrm{~N}_{2}$, and radioloytic $\mathrm{H}_{2}$ production and/or $\mathrm{O}_{2}$ generation on the metabolic processes and the composition of deep microbial ecosystems, such as in lithoautotrophic communities in a range of different subsurface systems (e.g., U-rich systems, seismically active zones, and high temperature (energy) regimes). What are the rates of formation of these "geogases", and how do the rates change with different settings, depth, and formation ages?

Oil, gas, and coal reservoirs form potential carbon and energy sources for deep microbial life. Thus, what is the relative importance of natural but also abiotic hydrocarbons for

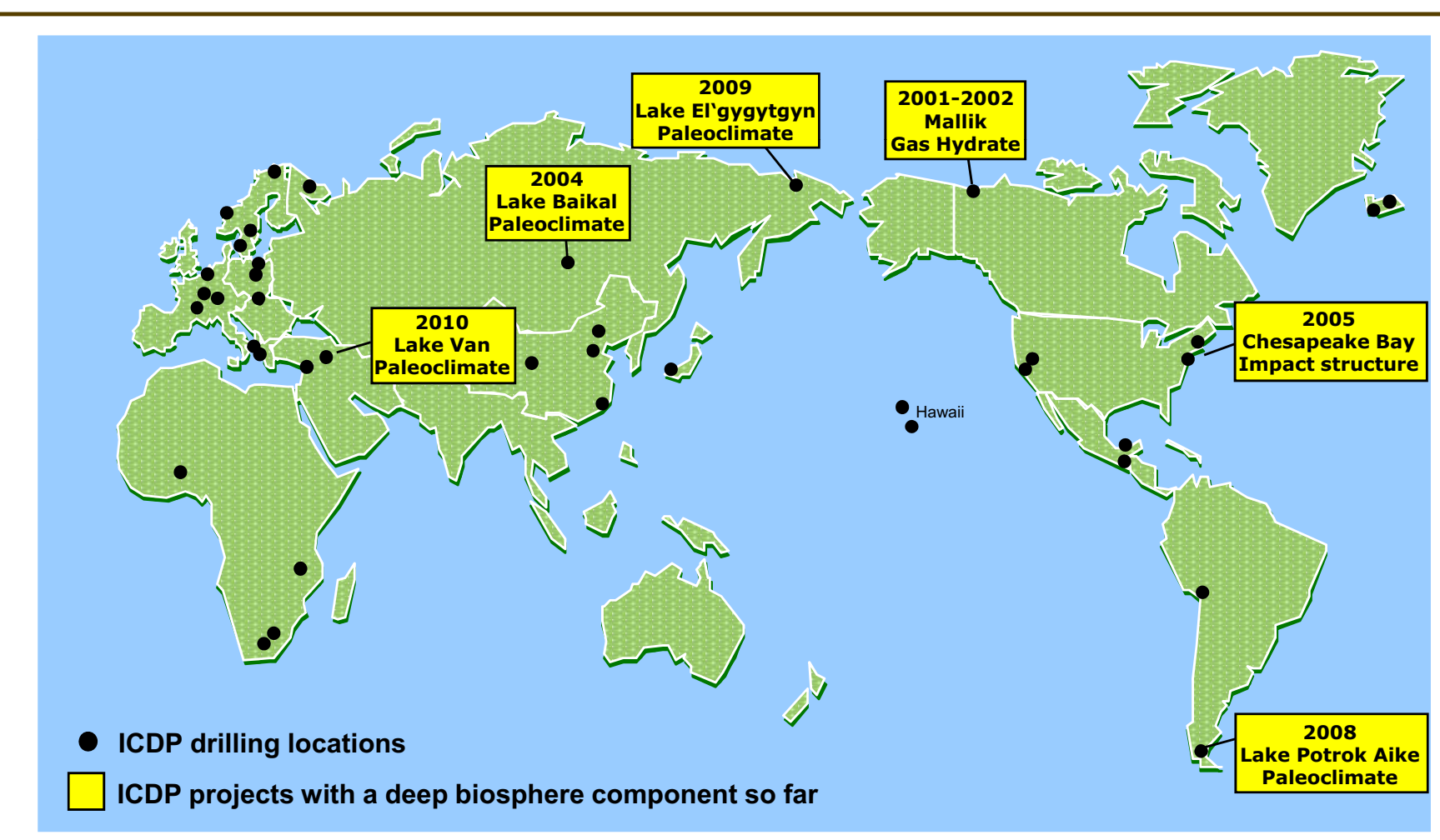

Figure 2. Map showing already completed ICDP projects with deep biosphere components (modified after Horsfield et al., 2007). 
supporting deep microbial communities? What role do deep microorganisms play in the formation and destruction of natural resources (oil, gas, coal), and how do their metabolisms influence the geochemistry and mineralogy of the subsurface (i.e., the deposition of ores)?

Also of interest is how natural and human perturbation affect subsurface ecosystems in time and space. For instance, how do deep microbial communities respond to earthquakes, mobilizing fluids (geogases), the disposal of waste, or the sequestration of $\mathrm{CO}_{2}$ (e.g., Ketzin, Germany or Columbia River basalts, U.S.A.)?

Microorganism populations interact with each other, and this raises further questions. What are the characteristics of such community interactions? What is the genomic inventory of deep microbial organisms? What are the effects of lateral gene transfer and the impact of mutations (incurred by cells that grow so slowly) on the evolution of cells in the deep subsurface? What is the role of phages in syntrophic interactions? Which genomic features support the adaptation and survival of microorganisms in the deep subsurface? Which DNA repair mechanisms do they apply? Why do cells in deep sediments (isolated) seem to be as little diverged as they are in the context of their $16 \mathrm{~S}$ ribosomal RNA gene or other genes?

Another important aspect is how subsurface microbial communities affect processes in the surface systems and vice versa. For the future climate development it is crucial to know how deep microorganisms affect Earth's climate, considering the production of the greenhouse gas methane, especially when permafrost areas are thawing (climate feedback). Furthermore, in reverse, what is the effect of climate change on the deep biosphere with regard to hydrological changes and nutrient supply? These aspects include the general question to the role of the deep biosphere in the global carbon cycle.

Finally, subsurface microbial ecosystems are also of specific interest from a biotechnological point of view. The deep biosphere contains a large pool of genes and enzymes that are potentially useful for biotechnological applications. Microbial processes are able to support the exploitation of ores (bioleaching, biomining), clean fuel, and energy from tar sands and other unconventional fossil energy resources. Specific naturally occurring microbial consortia might also be helpful for the bioremediation of polluted sites.

Upcoming ICDP projects for the integration of deep biosphere research. Although ICDP has already recognized the importance of deep biosphere research in terrestrial drilling operations (Horsfield et al., 2007), only the ICDP Mallik Gas Hydrate Research Project (Fig. 1) and the Chesapeake Bay Drilling Project (impact crater) have had major deep biosphere components so far (Fig. 2), including contamination controls during core retrieval. There was some limited bio- geochemical research in some lake sediment drilling projects as well: Lake Baikal, Potrok Aike Drilling (see Ariztegui et al., 2010 in this issue), and Lake El'gygytgyn. Although without contamination control, the paleoclimate drilling campaign in Lake Van, Turkey in 2010 also had a deep biosphere component.

In order to extend the number of projects with a deep biosphere component, the workshop identified a list of interesting upcoming ICDP projects where deep biosphere research might be added to already initiated projects. In particular, the ongoing ICDP lake drilling program appears to be an appropriate start to establish deep biosphere research in ICDP (for drilling locations see ICDP homepage, http:// www.icdp-online.org). The sediments of lakes provide a unique opportunity to characterize and investigate the subsurface microbial communities in many different climatic zones of the Earth and, therefore, under different environmental conditions. There are three interesting upcoming lake projects in the near future (discussed below).

Lake Ohrid (Macedonia/Albania) is considered to be the oldest continuously existing lake in Europe (assessed age 1-10 Ma). It has a unique aquatic ecosystem with more than 200 described endemic species. The sedimentary successions in the central basin seem to reflect the complete history of the lake being an excellent archive for climate and volcanic activity in the central northern Mediterranean region.

The Dead Sea (Israel, West Bank, and Jordan) is the deepest hypersaline lake in the world. The deep basin of the Dead Sea contains a continuous sedimentary record of Pleistocene to Holocene age which forms an archive for climatic, seismic, and geomagnetic history of the east Mediterranean region.

Lake Issyk-Kul (Kyrgyzstan) contains a long climatic archive of this environmentally sensitive region in central Asia. During this drilling campaign a focus is laid on the time frame through the Pliocene into the late to middle Miocene. However, the recent political developments in Kyrgyzstan may prevent this project from taking place in the near future.

In addition to the lake program there is a series of other currently upcoming projects also of interest for deep biosphere research due to the specific characteristics of the study areas. Upcoming projects are Campi Flegrei Caldera, Italy (active volcanic area, high geothermal gradient), the Eger Rift, Czech Republic (area with high release of mantle $\mathrm{CO}_{2}$ at the surface), and Collisional Orogeny in the Scandinavian Caledonides (COSC), Norway/Sweden (orogen dynamics, temperature gradient in the Caledonides, rock properties). More upcoming projects can be found at the ICDP homepage. 
Potential targets for a dedicated deep biosphere project within ICDP. Another aim of the workshop was to identify potential targets for a dedicated terrestrial deep biosphere drilling campaign, forming the core of a future science proposal within the scope of ICDP. Terrestrial environments provide a broad range of different geological settings with their various associated deep microbial communities. Thus, only a selection of some potential targets for scientific deep biosphere drilling campaigns is presented here (see text box).

- Drilling outward and deeper from within a deep mine (e.g., at the Deep Underground Science and Engineering Laboratory (DUSEL)) for sampling and establishing of a natural laboratory to conduct in situ experiments

- Drilling at sites of active serpentinization and other locations where lithoautotrophic communities might occur or play a significant role

- Coring and monitoring of an active fault zone (Eger Rift) and establishment of a natural laboratory to investigate the role seismicity plays in subsurface life

- Drilling along a sequence of oil-bearing rocks to examine biodegradation gradients (e.g., Western Canada and Paris Basin) and with a possible industry connection

- $\quad$ Coring different sedimentary basins with different thermal gradients, different depositional conditions, and organic carbon composition and concentrations to investigate questions on the biogeography of the deep biosphere and the fate of the organic matter as a substrate for deep microbial life

- Drilling at locations where permafrost may be actively releasing biogenic methane (e.g., the high arctic of Canada and Siberia), with a possible link to IODP drilling campaigns, offshore permafrost

- Drilling coal seams to investigate the role of the deep biosphere in coal bed methane generation

- Drilling into an active mud volcano to investigate the role of microbial activity in the generation and degradation of hydrocarbons

- Examining the types of microbes, processes, and activities associated with locations where carbon capture and storage is being attempted (e.g., Columbia River basalts, U.S.A.)

- Drilling a borehole in the backyard of a science institute to establish an easily accessible natural laboratory to perform in situ experiments

Furthermore, it was highlighted that each project needs to consider and implement the best methods for collecting high quality samples for microbiological, biogeochemical, and geochemical analysis. This would also entail augmenting the methods book that will be used by future ICDP microbiology efforts. The projects should generally include basic measurements of the geology, geochemistry, mineralogy, etc. so that the environmental context can be understood for interpreting the microbiological ecosystems. Finally, the need for a central data base for the results of the ICDP projects was emphasized.

\section{Technical, Administrative, and Logistical Prerequisites}

The fact that microbial cell abundance in subsurface environments is two to six orders of magnitude lower than at the surface makes the task of recovering uncontaminated supplies extremely difficult. Contamination control requires certain changes to standard drilling protocols, which can be achieved for a relatively small increase in cost when implemented already at an early planning stage. Also, handling and sampling procedures have to accommodate the special requirements to avoid alteration of the samples. Protocols like in IODP (Expedition 311 Scientists, 2006) have to be developed for ICDP drilling operations.

Preventing and assessing contamination. Due to the fact that basically all drilling operations use drilling fluids, contamination of cores through infiltration of drill fluid can only be minimized and not completely avoided. Uncontaminated samples are an absolute necessity for any subsequent analysis; therefore, contamination assessment is a crucial issue for geomicrobiological research in general.

In order to minimize contamination it is advisable to get involved in the planning of the drilling as early as possible, preferably as a Principal Investigator (PI), in order to have full control on the design of the operation. To achieve the best results in a cost effective way, it is also paramount to involve the drilling organization as early as possible. Any changes from standard drilling operations have to be taken into consideration early for the cost estimates; later changes can have dramatic effects on the overall budget. During the initial planning stage it is relatively easy to lay out the drilling operations according to geomicrobiology needs, even without compromising other research areas. Experience has shown that relatively few changes are necessary to minimize contamination of the samples. Most of these changes can be achieved relatively easily and for little extra cost if they are included in the planning at an early stage. Due to the great diversity of sediment/rock types to be drilled, the type of drilling equipment to be used, and other variables, there is no general rule on how to avoid contamination. Such an issue can only be addressed individually, given the specific circumstances.

During the drilling operation, standard microbiological procedures should be followed. While this is nothing new for a knowledgeable scientist, it may very well be so for the drilling staff. In order to ensure smooth drilling and sample handling, the drilling staff needs to be trained, and all procedures have to be discussed with and understood by them. 
Still, there are some general issues that help to minimize contamination. Steam cleaning of all drilling equipment has proven to be a relatively cheap but effective way to reduce contamination by removing any foreign rock fragments and hydrocarbons from old pipe grease. A complete sterilization of the entire equipment is usually not necessary because the material will be contaminated again by the time it has traveled down the borehole. When sterilizing equipment, one should always ask the question whether it will be possible to get the sample into the sampler (core barrel, water sampler) without anything non-sterile getting in contact with the sample. Only in such cases does sterilization of equipment really make sense. There are situations, such as water sampling in deep aquifers, where sterilization of samplers may be useful and necessary, but such decisions have to be made on a caseby-case basis.

The choice of drilling technique is of major importance. In few cases (short holes, hard rocks), it is possible to drill without any drilling fluid and use air- or gas-lift techniques instead. High volumes of pressurized air or nitrogen are used in place of conventional drilling fluids to circulate the well bore clean of cuttings and to cool the drill bit. Air drilling can be used where formations are dry, i.e., when there is no influx of water into the hole. Also, normally the specific gravity of the drill mud prevents the hole from closing around the drill string. Boreholes have to be stable to use this technique due to the low density of the gas. So far, there is little experience with this technique for geomicrobiological purposes.

For softer sediments, hydraulic piston coring is the method of choice because this technique has shown to provide the least contaminated samples with regard to penetration of drilling fluid into the core. This is not surprising as the coring itself does not require any drilling fluids and relies solely on the force with which the cutting shoe is driven into the sediment, followed by rotary drilling around the core to extend the diameter of the hole and to push the bottom hole assembly further down. In IODP operations, the advanced piston coring tool (APC) is the prime tool for recovering soft sediments. Although this technique provides the highest quality cores and should, therefore, be carried out as deep as possible, it reaches its limitations in consolidated sediments.

The biggest problems are still the sediments of intermediate stiffness that are too hard for piston and too soft for rotary coring. IODP uses the extended core barrel tool (XCB), but the retrieved samples are often unsuitable for geomicrobiology research because of the high level of contamination and drilling induced disturbances in the core. In many cases the recovered cores consisted of pieces of sediment floating in a solidified mixture of drill mud and cuttings. Rotary drilling becomes the method of choice in consolidated sediments and hard rocks. When using rotary coring, contamination control becomes absolutely crucial, because this technique requires drill fluids and, unlike situations with the APC tool, the core is in direct contact with the rotating drill head. Due to the high pressure of the drill fluid coming out of the drill bit, the rock can be saturated with drill mud several centimeters ahead of the bit.

Drilling should always be carried out with liners to protect the drilled core from further contamination and to ease later handling. Still there will always be some drill mud in the gap between the liner and the drill core, and this mud can seep inwards and contaminate the interior of the core. Additionally, natural or drilling-induced fractures provide pathways through which the mud may enter the core.

Careful adjustment of the drilling conditions, rapid evaluation of the quality of the recovered core material, and, if necessary, changes to the drilling protocol can help to minimize contamination, but some degree of contamination may be expected for all cores collected by rotary drilling. Still, cores suitable for geomicrobiological research can be obtained by this technique.

The composition of the drill fluid has to be monitored carefully; all components of the drill fluids, including the water, should be checked for possible contaminants prior to drilling. The high density of the drill mud is achieved through the addition of clays, which have considerable differences in the microbial load. There is anecdotal evidence that synthetic clays usually contain fewer microbial cells than natural ones, but so far there is no systematic study about the microbial load of different clays. If possible, organic additives (thickeners, emulsifiers, stabilizers, etc.) should be limited to an absolute minimum because they represent a nutrient source for the microbes and can thereby enhance microbial activity. Hydrocarbon-based additives should be avoided at any cost as they interfere with most organic geochemical analyses.

A careful evaluation of all materials during the early planning stage can, therefore, significantly reduce the potential for contamination. Independent of the drilling technique and the composition of the drill mud, some contamination will always occur; therefore, contamination has to be assessed, preferably by multiple techniques.

The most common technique for contamination assessment is the use of fluorescent microspheres. These particles are available in a wide range of sizes $(0.5 \mu \mathrm{m}$ diameter is most common for contamination assessment). Microspheres have the advantage that they can be easily detected by fluorescence microscopy. Having a density very close to $1 \mathrm{~g} \mathrm{cc}^{-1}$, microspheres can be easily separated from the sample by density centrifugation on a cushion of sodium chloride solution. The disadvantage of microspheres is their price, which can add significantly to the total cost of a project. 
There are two different ways to apply the microspheres. For hydraulic piston coring the easiest way is to attach small bags filled with spheres to the inner front of the core. As soon as the sediment enters the core barrel, the bag is ripped and the microspheres mix with the drilling fluid and eventually infiltrate the core. Using this technique the concentration of spheres in the mud is not constant and can only roughly be estimated; therefore, it is difficult to assess precisely how much drill fluid per volume of sediment has to enter the core in order to be detected by this technique. Still, this technique has been used for many years in IODP operations with very reliable results. Another way to apply microspheres is to add them directly to the drill mud. In cases where only a few depth intervals are being cored for geomicrobiological analysis, they can be added with a peristaltic pump into the intake of the mud pump. This way, the amount of microspheres can be limited to an absolute minimum. In cases where many depths are being cored, the entire volume of drill mud has to be amended with microspheres. Depending on the well depth and the required volume of drill mud, this approach may quickly reach cost limits. In order to detect sufficiently small concentrations of drill mud in the core, the concentration of microspheres should be at least around $1000 \mu \mathrm{L}-1$. Depending on the diameter of the hole and the target depth, the volume of drill mud can vary between single and tens of cubic meters or even more. Microspheres are removed from the mud by various processes (Kallmeyer et al., 2006) and have to be added in regular intervals. Also, large volumes of drill mud can get lost in fractures and have to be replaced by fresh mud, requiring additional addition of microspheres. All these processes have to be taken into account when calculating the number of necessary microspheres.

The addition of known and easily identifiable microorganisms would be an alternative type of particulate tracers. However, this approach will possibly cause major legal problems in many if not most areas.

Solute tracers may offer a viable alternative to added allochthonous microbes and microspheres. In IODP operations perfluorocarbon tracer (perfluoromethylcyclohexane, PFT) has been used on several occasions with good results, although the data may differ somewhat from those obtained with microspheres (Smith et al., 2000a, 2000b). PFT is much cheaper than microspheres, but its detection requires a gas chromatograph, which may cause logistical problems on the drill site. Although this technique is very sensitive, possible incompatibilities with the drill mud matrix have to be evaluated prior to drilling. Also, the samples have to be taken quickly after retrieval of the core, due to the high volatility of PFT.

During the ICDP Chesapeake Bay impact drilling, halon was used as a tracer. Although the results were satisfactory, this technique will most probably not be used in future drilling operations because of the decreasing availability of Halon as it becomes banned in many countries due to its deleterious effects on the ozone layer.

Fluorescent dyes can be detected by fluorometry, which is a relatively easy and robust technique, allowing for analysis right at the drill site. This may be very helpful in cases where unforeseen changes in drilling operations become necessary, and possible influences on the quality of the recovered material need to be evaluated on the spot. A variety of fluorescent dyes have been used successfully in various operations: rhodamine WT, uranine, lissamine FF, fluorescine, amino $\mathrm{G}$ acid (7-Amino-1,3-naphthalenedisulfonic acid). However, quenching of the fluorescence signal due to coloration of the sample may complicate the exact quantification of the infiltration of drill mud into the core.

The level of contamination can vary on a small scale, not just in terms of distance from the outside of the core but also between different sample depths. The drill mud may have infiltrated the core along small cracks, which are not visible upon manual inspection of the core; therefore, even if adjacent contamination controls are "clean", that may not guarantee an uncontaminated sample. Ideally, contamination should be assessed on the sample being analyzed. Redundancy of contamination control is important; at least two different methods should be used in order to ensure good contamination control under all circumstances.

Sampling and sample storage. After the cores are retrieved, sample collection is the next major step. The contaminated outer part of the core has to be removed. Only the uncontaminated inner part can be used for geomicrobiological research (inner coring technique). How much of the outer part needs to be removed and how much uncontaminated material actually becomes available for analysis have to be determined individually. If anaerobic conditions are required for the sample material, sampling has to be conducted in an anaerobic glove box.

Sampling techniques have to be adjusted according to lithology. In soft sediments subsampling can be done with cut-off syringes, whereas in hard sediments the center subcore has to be retrieved by drilling. Cut-off plastic syringes are cheap and can be prepared in large quantities prior to drilling. Metal core drills for hard sediments are much more expensive and usually not available in the same quantities as syringes. The effort in time and manpower of recycling these drills (retrieval of sample, cleaning, sterilization) has to be taken into account when planning the amount of samples that can be processed in a given time.

Sample preservation is another important issue. There are different approaches currently being used, depending on the parameter to be preserved. The standard technique for storage of cell count samples from soft sediment is a solution of similar salinity with formalin. A common method for general geochemical sampling is to put the whole sediment into 
gas-tight bags flushed with nitrogen and/or containing an oxygen scrubber. Such samples have proven to be a good option for further subsampling in the laboratory.

Another option would be gel preservation. The sample is coated with an antimicrobial gel that prevents surface growth and limits gas exchange. In some cases special waxes with a low melting point have been used to coat samples. However, the application of this technique has so far been limited to samples for physical and chemical analysis, not microbiology. There are no data available whether these waxes give off any volatile compounds that could potentially be used as a carbon source by microbes.

Pore water should be extracted as quickly as possible to avoid alteration during storage. Squeezing yields the highest amounts of pore water but destroys the sediment structure. Rhizon samplers are not as effective but leave the sediment structure intact, thereby allowing the use of the core for other purposes. However, Rhizon samplers apply a vacuum to the retrieved pore water, thus causing the loss of gases, especially $\mathrm{CO}_{2}$. This loss in $\mathrm{CO}_{2}$ will inevitably alter the $\mathrm{pH}$ of the sample. Although not very efficient, centrifugation can be the method of choice for highly porous and soft sediments.

Samples should be stored according to the parameter to be analyzed. Storage at $4^{\circ} \mathrm{C}$ is preferred for turnover rate measurements and cell counting. For molecular analysis, storage at $-20^{\circ} \mathrm{C}$ may not be cold enough to stop all degradation processes. The best method is still storage in liquid nitrogen, because at that temperature all degradation processes are stopped and oxidation is completely avoided. However, liquid nitrogen may not be available in remote locations, and transport may also be an issue, although with special containers samples can even be sent by airfreight in liquid nitrogen.

Integration of a standard minimum sampling scheme. Compared to the marine realm, terrestrial subsurface microbiology is lagging behind by many years. One of the main reasons for this is the lack of available samples. A minimum sampling scheme that could become a compulsory standard component of all ICDP drilling operations could help to overcome this lack of material. Such a minimum sampling scheme would not interfere with other analyses and could be done with relatively little additional effort. Like in IODP, certain physical parameters should also be measured routinely in order to advance our understanding of subsurface biomass, activities, and habitability. These data would be extremely helpful not just for geomicrobiological research but for other fields as well. Routine measurements should include formation factor as well as downhole temperature and pressure. There have to be at least two different minimum sampling schemes, one for soft and one for hard sediments.
For soft sediments the minimum requirements would be:

- Pore water via Rhizon sampler, split into acidified and chilled aliquots. Such a sample cannot be used for quantification of dissolved inorganic carbon (DIC) or alkalinity due to loss of $\mathrm{CO}_{2}$. For such measurements a squeezed sample would be preferable. In cases where only one technique can be applied, the Rhizon samplers are still preferable, unless the $\mathrm{CO}_{2}$-sensitive parameters are of major interest.

- Cell count sample (2-cc syringe sample, stored in $2 \%$ formalin), in cases where no contamination control can be made, the sample should be taken from the absolute center of the core and as far away as possible from any visible cracks.

- Dissolved gases sample (2-cc syringe sample, stored in $10 \% \mathrm{NaOH}$ )

- Elemental parameters (CHN sample): 2-cc sample, stored at $-20^{\circ} \mathrm{C}$ or colder.

- A short whole round core or a large $(60 \mathrm{cc})$ syringe frozen at $-80^{\circ} \mathrm{C}$ for future molecular studies. The cost of such studies is declining rapidly, and the samples will be invaluable.

For hard material the minimum requirement would be a drilled subcore sample, stored in a gas-tight bag, flushed with nitrogen and/or equipped with an oxygen scrubber, stored at $4^{\circ} \mathrm{C}$.

So far, subsurface microbiology in ICDP projects has mainly been done as "one-off" operations, with contamination control and sample handling protocols being developed individually for the specific projects. These individual approaches make it rather difficult to compare data from different projects. By making the minimum sampling schemes a standard part of ICDP operations, a much wider community could use these data.

Data storage. Storage of the logging data can be managed rather easily through the ICDP Operations Support Group (OSG), whereas storage of legacy samples is a much more complicated issue because there are no central storage facilities for ICDP cores. Although legacy samples form a valuable resource for future research, they also represent a great burden and cost factor. As this is an issue that is not just affecting geomicrobiology, it should be addressed on a larger scale.

Drilling and mobile laboratory facilities. ICDP drilling operations are much more diverse with regard to drilling equipment and work environment than at IODP, where the drill ships operate according to well-known standard procedures and provide a good working environment. Still, a large fraction of ICDP operations employs the same drilling equipment, namely the DOSECC rigs and, in the future, the INNOVA Rig as well. A test drilling operation was carried out with DOSECC's Glad 800 Rig at Great Salt Lake, which 
allowed for equipment testing and, due to the vicinity of DOSECC headquarters, immediate refinement and modification of equipment in the workshop when necessary. There should also be the opportunity for a geomicrobiology test drill to develop and refine the required drilling protocols for biogeochemical and microbiological research. Such an operation should be science driven as opposed to being just a technical exercise, but the geologic setting has to be well known in order to avoid any problems due to unforeseen lithological changes. It would, therefore, be a good option to add such a test drill onto an already scheduled drilling operation. Whereas normal drilling operations are usually run to a rather tight schedule, it is important to allocate sufficient additional time and resources for the testing and not to squeeze this into the already tight schedule of the general project.

For geomicrobiological research, sample processing immediately after retrieval is important to avoid alteration of the samples. Sufficiently equipped laboratories are readily available on the IODP drill ships. This is much different for ICDP operations, where quite often they are located in remote areas with more complicated or impossible access to a suitable laboratory. One solution to this problem is the new BUGLab facility of the Helmholtz Centre Potsdam (GFZ) German Research Centre for Geosciences (Fig. 3). The laboratory is composed of two portable standard 20-ft containers, which can be combined if necessary. Due to their modular structure, the BUGLab containers can be equipped according to the specific requirements of the planned work, allowing the processing of microbiological and biogeochemical samples, on-site analysis of biologically significant transient properties, and on-site analysis of chemical and physical properties that are being useful to guide microbiological and biogeochemical sampling strategies.

\section{Workshop Participants}

Lorenz Adrian, UFZ Leipzig, Germany; Rick Colwell, Oregon State University, U.S.A.; Steve D'Hondt, University of Rhode Island, U.S.A.; Clemens Glombitza, GFZ Potsdam, Germany; Ulrich Harms, ICDP, Germany; Ian Head, Newcastle University, UK; Kai-Uwe Hinrichs, MARUM-University of Bremen, Germany; Nils Holm, Stockholm University, Sweden; Brian Horsfield, GFZ Potsdam, Germany; Merja Itävaara, VTT Technical Research Centre of Finland; Jens Kallmeyer, University of Potsdam, Germany; Thomas L. Kieft, New Mexico Institute of Mining and Technology, U.S.A.; Kirsten Küsel, Friedrich Schiller University Jena, Germany; Kai Mangelsdorf, GFZ Potsdam, Germany; Martin Mühling, TU Bergakademie Freiberg, Germany; Richard W. Murray, Boston University, Earth Sciences, U.S.A.; Dennis Nielson, DOSECC, U.S.A.;T.C. Onstott, Princeton University, U.S.A.; R. John Parkes, Cardiff University, U.K.; Karsten Pedersen, University of Gothenburg, Sweden; Matxalen Rey Abasolo, OSG at ICDP, Germany; Axel Schippers, BGR Hannover, Germany; Michael Schlömann, TU Bergakademie

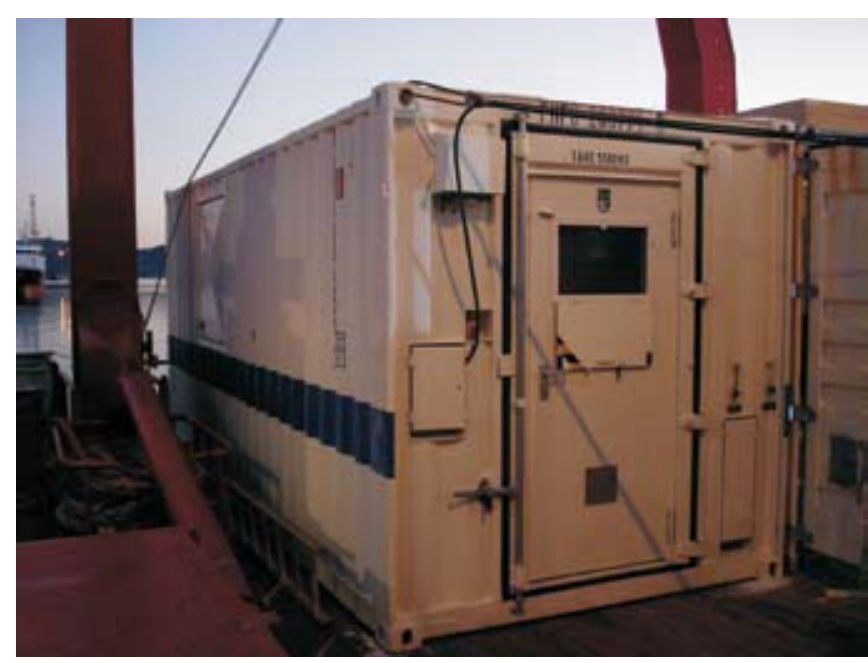

Figure 3. The GFZ BUGLab container is a mobile field laboratory for geomicrobiological and biogeochemical research. The container can be deployed in a wide range of both marine and terrestrial settings, from polar to tropical environments.

Freiberg, Germany; David Smith, University of Rhode Island, U.S.A.; Yohey Suzuki, National Institute of Advanced Industrial Science \& Technology, Japan; Volker Thiel, University of Göttingen, Germany; Andrea Vieth, GFZ Potsdam, Germany; Mary Voytek, U.S. Geological Survey, U.S.A.; Maren Wandrey, GFZ Potsdam, Germany; Claudia Wiacek, TU Bergakademie Freiberg, Germany; Heinz Wilkes, GFZ Potsdam, Germany; Matthias Zabel, MARUMUniversity of Bremen, Germany; Klaus-Gerhard Zink, GNS Science, New Zealand

\section{References}

Colwell, F.S., Nunoura, T., Delwiche, M.E., Boyd, S., Bolton, R., Reed, D.W., Takai, K., Lehman, R.M., Horikoshi, K., Elias, D.A., and Phelps, T.J., 2005. Evidence of minimal methanogenic numbers and activities in sediments collected from JAPEX/ JNOC/GSC et al. Mallik 5L-38 gas hydrate production research well. In Dallimore, S.R., and Collett, T.S. (Eds.), Scientific Results from the Mallik 2002 Gas Hydrate Production Research Well Program, Mackenzie Delta, Northwest Territories, Canada. Geological Survey of Canada, Bulletin 585:1-11.

Engelen, B., Engelhardt, T., Sahlberg, M., and Cypionka, H., 2009. Viral infections as controlling factors of the deep biosphere. National IODP-ICDP meeting in Potsdam, Germany. 16-18 March 2009:52 pp.

Expedition 311 Scientists, 2006. Methods. In Riedel, M., Collett, T.S., Malone, M.J., and the Expedition 311 Scientists. Proc. IODP, 311: Washington, DC (Integrated Ocean Drilling Program Management International, Inc.). doi:10.2204/iodp.proc. 311.102.2006.

Fredrickson, J.K., and Onstott, T.C., 1996. Microbes deep inside the Earth. Sci. Am., 275:42-47, doi:10.1038/scientificamerican 1096-68.

Glombitza, C., Mangelsdorf, K., and Horsfield, B., 2009. A novel procedure to detect low molecular weight compounds released by alkaline ester cleavage from low maturity coals to assess its feedstock potential for deep microbial life. Organ. 
Geochem., 40:175-183, doi:10.1016/j.orggeochem.2008. 11.003.

Gohn, G.S., Koeberl, C., Miller, K.G., Reimold, W.U., Browning, J.V., Cockell, C.S., Horton, J.W., Kenkmann, T., Kulpecz, A.A., Powars, D.S., Sanford, W.E., and Voytek, M.A., 2008. Deep drilling into the Chesapeake Bay impact structure. Science, 320:1740-1745, doi:10.1126/science.1158708.

Horsfield, B., Kieft, T., Amann, H., Franks, S., Kallmeyer, S., Mangelsdorf, K., Parkes, J., Wagner, W., Wilkes, H., and Zink, K.-G., 2007. The GeoBiosphere. In Harms, U., Koeberl, C., and Zoback, M.D. (Eds.), Continental Scientific Drilling: A Decade of Progress and Challenges for the Future. BerlinHeidelberg (Springer), 163-211.

Horsfield, B., Schenk, H.J., Zink, K.-G., Ondrak, R., Dieckmann, V., Kallmeyer, J., Mangelsdorf, K., di Primio, R., Wilkes, H., Parker, J., Fry, J.C., and Cragg, B., 2006. Living microbial ecosystems within the active zone of catagenesis: implications for feeding the deep biosphere. Earth Planet. Sci. Lett., 246:55-69.

Kallmeyer, J., Mangelsdorf, K., Cragg, B.A., Parkes, R.J., and Horsfield, B., 2006. Techniques for contamination assessment during drilling for terrestrial subsurface sediments. Geomicrobiol. J., 23:227-239, doi:10.1080/014904506007 24258 .

Lin, L.-H., Hall, J., Lippmann-Pipke, J., Ward, J.A., Sherwood Lollar, B., DeFlaun, M., Rothmel, R., Moser, D., Gihring, T.M., Mislowack, B., and Onstott, T.C., 2005. Radiolytic $\mathrm{H}_{2}$ in continental crust: nuclear power for deep subsurface microbial communities. Geochem. Geophys. Geosyst., 6:Q07003, doi: 10.1029/2004GC000907.

Lin, L.-H., Wang, P.-L., Rumble, D., Lippmann-Pipke, J., Boice, E., Pratt, L.M., Sherwood Lollar, B., Brodie, E.L., Hazen, T.C., Andersen, G.L., DeSantis, T.Z., Moser, D.P., Kershaw, D., and Onstott, T.C., 2006. Long-term sustainability of a highenergy, low diversity crustal biome. Science, 314:479-482, doi:10.1126/science.1127376.

Lipp, J.S., Morono, Y., Inagaki, F., Hinrichs, K.-U., 2008. Significant contribution of Archaea to extant biomass in marine subsurface sediments. Nature 454:991-994. doi:10.1038/nature 07174 .

Mangelsdorf, K., Haberer, R.M., Zink, K.-G., Dieckmann, V., Wilkes, H., and Horsfield, B., 2005. Molecular indicators for the occurrence of deep microbial communities at the Mallik 5L-38 gas Hydrate Research Well. In Dallimore, S.R. and Collett, T.S. (Eds.), Scientific Results from the Mallik 2002 Gas Hydrate Production Research Well Program, Mackenzie Delta, Northwest Territories, Canada. Geological Survey of Canada, Bulletin 585:1-11.

Parkes, R.J., Cragg, B.A., and Wellsbury, P., 2000. Recent studies on bacterial populations and processes in subseafloor sediments: a review. Hydrogeol. J., 8:11-28, doi:10.1007/ PL00010971.

Parkes, R.J., Wellsbury, P., Mather, I.D., Cobb, S.J., Cragg, B.A., Hornibrook, E.R.C., and Horsfield, B., 2007. Temperature activation of organic matter and minerals during burial has the potential to sustain the deep biosphere over geological timescales. Organ. Geochem., 38:845-852, doi:10.1016/j. orggeochem.2006.12.011.

Pedersen, K., 2000. Exploration of deep intraterrestrial microbial life: current perspectives. FEMS Microbiol. Lett., 185:9-16, doi:10.1111/j.1574-6968.2000.tb09033.x.

Rothschild, L.J., and Mancinelli, R.L., 2001. Life in extreme environments. Nature, 409:1092-1101, doi:10.1038/35059215.

Roussel, E.G., Cambon Bonavita, M.-A., Querellou, J., Cragg, B.A., Webster, G., Prieur, D., and Parkes, R.J., 2008. Extending the sub-sea-floor biosphere. Science, 320:1046, doi:10.1126/ science. 1154545 .

Sherwood Lollar, B., Lacrampe-Couloume, G., Slater, G.F., Ward, J.A., Moser, D.P., Gihring, T.M., Lin, L.-H., and Onstott, T.C., 2006. Unravelling abiogenic and biogenic sources of methane in the Earth's deep subsurface. Chem. Geol., 226:328-339, doi:10.1016/j.chemgeo.2005.09.027.

Smith, D.C., Spivack, A.J., Fisk, M.R., Haveman, S.A., and Staudigel, H., 2000a. Tracer-based estimates of drilling-induced microbial contamination of deep-sea crust. Geomicrobiol. J., 17:207-219, doi:10.1080/01490450050121170.

Smith, D.C., Spivack, A.J., Fisk, M.R., Haveman, S.A., Staudigel, H., and Party, O.L.S., 2000b. Methods for quantifying potential microbial contamination during deep ocean drilling. $O D P$ Tech. Note, 28.

Stevens, T.O., and McKinley, J.P., 1995. Lithoautotrophic microbial ecosystems in deep basalt aquifers. Science, 270:450-454, doi:10.1126/science.270.5235.450.

Vuillemin, A., Ariztegui, D., Vasconcelos, C., and the PASADO Scientific Drilling Party, 2010. Establishing sampling procedures in lake cores for subsurface biosphere studies: assessing in situ microbial activity, Sci. Drill., 10:35-39, doi: 10.2204/iodp.sd.10.04.2010.

Wellsbury, P., Goodman, K., Barth, T., Cragg, B.A., Barnes, S.P., and Parkes, R.J., 1997. Deep marine biosphere fuelled by increasing organic matter availability during burial and heating. Nature, 388:573-576, doi:10.1038/41544.

Whitman, W.B., Coleman, D.C., and Wiebe, W.J., 1998. Prokaryotes: the unseen majority. Proc. Natl. Acad. Sci. USA, 95:6578-6583, doi:10.1073/pnas.95.12.6578.

Wilhelms, A., Larter, S.R., Head, I., Farrimond, P., di-Primio, R., and Zwach, C., 2001. Biodegradation of oil in uplifted basins prevented by deep-burial sterilization. Nature, 411:1034-1037, doi:10.1038/35082535.

Zink, K.-G., Wilkes, H., Disko, U., Elvert, M., and Horsfield, B., 2003. Intact phospholipids - microbial "life markers" in marine deep subsurface sediments. Organ. Geochem., 34:755-769, doi:10.1016/S0146-6380(03)00041-X.

\section{Authors}

Kai Mangelsdorf, Helmholtz Centre Potsdam, GFZ German Research Centre for Geosciences, Telegrafenberg, 14473 Potsdam, e-mail: K.Mangelsdorf@gfz-potsdam.de.

Jens Kallmeyer, University of Potsdam, Earth and Environmental Sciences, Karl-Liebknecht Str. 25, 14476 Potsdam, e-mail:kallm@geo.uni-potsdam.de.

\section{Photo Credits}

Fig. 1 - ICDP

Fig. 3 - Kai Mangelsdorf, GFZ Potsdam 